\title{
Near-surface phytoplankton pigment from the Coastal Zone Color Scanner in the Subantarctic region southeast of New Zealand
}

\author{
Karl Banse*, David C. English** \\ University of Washington, School of Oceanography, Box 357940, Seattle, Washington 98195-7940, USA
}

\begin{abstract}
Primarily based on satellite images, the phytoplankton concentration southeast (downstream) of New Zealand in the High Nitrate - Low Chlorophyll (HNLC) Subantarctic water between the Subtropical Convergence (STC) and the Polar Front (PF) is believed to be higher than in the remainder of the Pacific Sector. Iron enrichment is assumed to be the reason. To study the question, near-surface phytoplankton pigment estimates from the Coastal Zone Color Scanner for up to $7 \mathrm{yr}$ were reprocessed with particular attention to interference by clouds. Monthly mean images were created for the U.S. JGOFS Box along $170^{\circ} \mathrm{W}$ and means for individual dates calculated for 7 large areas between $170^{\circ} \mathrm{E}$ and $160^{\circ} \mathrm{W}, 45^{\circ}$ and $58^{\circ} \mathrm{S}$, well offshore of New Zealand and principally between and away from the STC and PF. The areal means are about as low as in other HNLC regions (most values between 0.1 and 0.4 or $0.5 \mathrm{mg} \mathrm{m}^{-3}$, with very few winter images; median of seasonal means, $0.26 \mathrm{mg} \mathrm{m}^{-3}$ ) except at times near the STC. The higher means tend to occur in late summer and autumn. However, contrary to expectations, neither the PF nor the environs of the Subantarctic Front are distinguished by a zone of increased pigment. Also, of 24 spring-summer images of oceanic islands in mostly pigment-poor water, 17 yielded no recognizable elevated pigment; islands were 5 times surrounded by approximately doubled concentrations (ca $100 \mathrm{~km}$ in diameter), and 2 cases may have been associated with an extensive bloom. Inspection of offshore images showed concentrations of $\geq 1$ (up to 5) $\mathrm{mg} \mathrm{m}^{-3}$ in rare patches of 65 to $200 \mathrm{~km}$ size on approximately one-tenth of the dates; such patches were not seen in Subantarctic waters of the eastern Pacific Sector. A case is made for Australian airborne iron supply being the cause that, presumably, would enhance large-celled phytoplankton. Since, however, the putative iron supply from the seabed around the oceanic islands or the near-by Campbell Plateau normally does not lead to phytoplankton increase, patches of neritic mesozooplankton advected from the shelves might be another mechanism that generates blooms of small-celled phytoplankton, but there are no data. These alternatives can easily be field-tested from concentration and size composition of the phytoplankton.
\end{abstract}

KEY WORDS: Chlorophyll $\cdot$ CZCS $\cdot$ HNLC region $\cdot$ Iron $\cdot$ New Zealand $\cdot$ South Pacific $\cdot$ Subantarctic

\section{INTRODUCTION}

The Subantarctic water ring, here defined as being between the Subtropical Convergence (STC) and the Polar Front (PF, also Antarctic Convergence), forms the High Nutrient (Nitrate)-Low Chlorophyll (HNLC) region of the Southern Ocean. While high nutrient concen-

-E-mail: banse@ocean.washington.edu

- Present address: Dept. of Marine Sciences, University of South Florida, 140 Seventh Ave. S., St. Petersburg, Florida 33701-5016, USA trations were previously observed from ships (see below), the circum-Antarctic feature of year-round low mean values of phytoplankton pigment was first demonstrated by NASA's Coastal Zone Color Scanner (CZCS; McClain et al. 1991, Comiso et al. 1993). Banse (1996) reviewed the available in situ chlorophyll data from the Pacific and Indian Subantarctic sectors. He concluded from the lack of correlation of surface chlorophyll concentrations with mixed-layer depth that underwater irradiance, and hence algal division rates, did not determine the pigment concentrations in the region. The iron supply, inferred to be small because of 
low aeolian input, was unlikely to cause the low pigment values directly; instead, the scarcity of iron would cause the prevalence of very small phytoplankton cells, which seem to divide at significant rates. The phytoplankton concentrations in the HNLC regime of the open sea were regarded as being kept low by grazing of small zooplankton, which recycles iron similarly to other nutrients (cf. Hutchins \& Bruland 1994).

Superimposed on the low background levels of Subantarctic surface pigment in the CZCS-derived maps, however, are elevated concentrations extending for thousands of kilometers downstream of South America and not quite that far downstream of Australia and New Zealand (Sullivan et al. 1993 and Comiso et al. 1993 from combining all CZCS data, Harris et al. 1993 for individual months of spring/summer of 1981/82). Ships also frequently observed high concentrations ( $1 \mathrm{mg} \mathrm{m}^{-3}$ to blooms of a very few $\mathrm{mg} \mathrm{m}^{-3}$ ) in major hydrographic fronts elsewhere in the Subantarctic HNLC region. These enhancements are not surprising for the STC where northern oligotrophic and southern. Subantarctic waters, rich at least in $\mathrm{N}$ and $\mathrm{P}$, are meeting. In contrast, the reasons for blooms in the major fronts of the Southern Ocean (PF and the Subantarctic Front, SAF, to the north, see Fig. 1) where 2 nutrientrich waters mix, are not obvious, even less so when underwater irradiance and stability of the water column do not appear to play a role, as stated. In the PF of the Atlantic Sector, however, Baar et al. (1995) found a significant iron supply from depths beneath that was accompanied by high chlorophyll in the euphotic zone. Earlier, in sections across the SAF and the PF south of Africa, Laubscher et al. (1993) had observed a marked increase of large cells (diatoms) over a rather consistently low background of small cells. Banse (1996) combined these data and interpreted the size change as enhanced growth of previously iron-starved large cells that could not be kept in check by the prevailing small grazers which continued to control the populations of small cells. $\mathrm{He}$ also noted reports of large cells at Subantarctic and Antarctic islands, where iron would be supplied from the sea bed, and suggested that regular temperate phytoplankton cycles with seasonal blooms might prevail near the islands, like those on temperate and subpolar continental shelves elsewhere (an additional data set in Leakey et al. 1994, Fig. 2 therein). As suggested by
Sullivan et al. (1993), the increased pigment concentration in the Subantarctic waters downstream of major landmasses might similarly be explained by enhanced iron supply. The implication, noted herein, would be that large cells are abundant offshore in water with. markedly increased chlorophyll content.

Somewhat similar to the satellite observations, the only relatively high surface pigment values (a mean of $0.5 \mathrm{mg} \mathrm{m}^{-3}$ ) from the entire Pacific Sector occur in the available ship-collected data downstream of New Zealand, and perhaps significantly, in austral summer (Banse 1996). That review missed the multi-year compilation for New Zealand waters by Bradford (1980), which was reproduced in Heath \& Bradford (1980) for the environs of the Campbell Plateau. The observations covered November to January and showed chlorophyll values up to $2 \mathrm{mg} \mathrm{m}^{-3}$ just west of the region to be studied herein (Box 1, Fig. 1). Values between 0.5 and almost $1.0 \mathrm{mg} \mathrm{m}^{-3}$ were estimated within the region, surrounded by water with the normal Subantarctic concentrations of $<0.25$ or even $<0.1 \mathrm{mg} \mathrm{m}^{-3}$. Also, Bradford's (1980) map tentatively suggested an area with $>0.5 \mathrm{mg} \mathrm{m}^{-3}$ pigment south of $50^{\circ} \mathrm{S}$ and east of $180^{\circ}$, clearly north of the PF. It was based on an extrapolation of a line of stations of

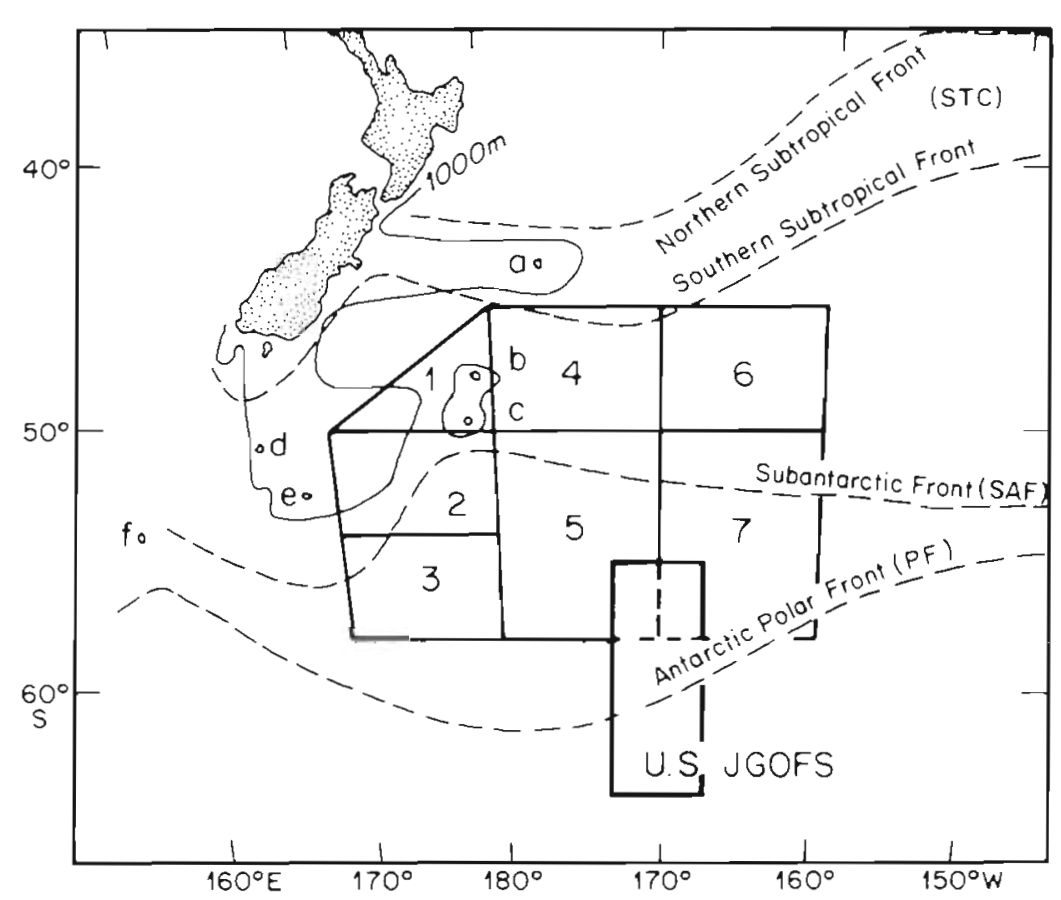

Fig. 1 Location of U.S. JGOFS Box and of Boxes 1-7. Outlines and fronts from Belkin (1988), with the position of the Southern Subtropical Front close to New Zealand (including the Southland Front) modified from Heath (1985). Isobath for $1000 \mathrm{~m}$ only shown south and east of South Island. a: Chatham Is. on the Chatham Ridge; b: Bounty Is.; c: Antipodes Is.; d: Auckland Is.; e: Campbell Is.;

f: Macquarie Is. The Campbell Plateau is approximately circumscribed by the isobath running from ' $d$ ' through Boxes 2 and 1 toward New Zealand 
'Eltanin' Cruise 15 of November 1964 (Burkholder \& Burkholder 1967). After multiplication by 0.75 (Banse \& Anderson 1967), however, the $0.5 \mathrm{mg}$ line in the southeast of Bradford's (1980) figure would vanish. Prior to the emergence of the iron hypothesis, Heath \& Bradford (1980) reported for the Campbell Plateau at depths $>450 \mathrm{~m}$ that chlorophyll and density differences between the surface and $75 \mathrm{~m}$ (ranging from $<0.1$ to 0.3 sigma-t units) were correlated at $\mathrm{p}<0.05$. Note, however, that their $r=0.30$ implies that only $9 \%$ of the correlation was explained by the density difference so that it is worth looking for causes of high chlorophyll concentrations other than stability and the inferred underwater irradiance. New chlorophyll data from north of the SAF, at $10 \mathrm{~m}$ depth, were published by Hawes et al. (1997; late summer, a mean of $0.25 \mathrm{mg}$ $\mathrm{m}^{-3}, \mathrm{n}=9$ ) and Safi \& Hall (1997; 0.12 and $0.20 \mathrm{mg} \mathrm{m}^{-3}$, 2 stations each for winter and spring, respectively).

The area southeast of New Zealand is of current interest. In the framework of the international Joint Global Ocean Flux Study (JGOFS), Southern Oceans, it is the northern site of seasonal cruises by the United States, starting in late 1997 under AESOPS, the Antarctic Environment Southern Ocean Process Study (Anderson \& Smith 1995, Fig. 2 therein). For the present paper, the 'JGOFS Box' is circumscribed by $3^{\circ}$ each on both sides of $170^{\circ} \mathrm{W}$, and from $55^{\circ}$ to $64^{\circ} \mathrm{S}$. It straddles the PF (Fig. 1).

With this biological background, the goals of the paper are as follows: After reprocessing the data collected by the CZCS between 1978 and 1986, (1) present and describe the spatial and temporal pigment distribution in the JOGFS Box from monthly CZCS composites; (2) describe the seasonal and interannual variability of near-surface pigment for the offshore Subantarctic waters between $45^{\circ}$ and $58^{\circ} \mathrm{S}, 170^{\circ} \mathrm{E}$ and $160^{\circ} \mathrm{W}$ from large-scale means of daily images; (3) investigate from visual inspection of daily images whether the Subantarctic and Polar fronts and the islands in the region may be associated with pigment increases.

Aside from the discussion of the JGOFS Box, the purpose is to proceed beyond the previous studies, especially those based on the CZCS, that used grand temporal and spatial averages, and to study phenomena lasting less than a month, as well as to address spatial features that may be encountered by ships. This attempt is imbedded in a description and discussion of the region southeast of New Zealand as a HNLC region, which is noteworthy because of the proximity of land and the presence of a submarine plateau and open-ocean islands.

Principally, in addition to depicting monthly data from the JGOFS Box, seasonal and interannual variability based on daily means will be presented for 7 large boxes (Fig. 1). They are placed away from the coastal influence of New Zealand, as well as from the Polar Front to the south and the newly recognized Southern Subtropical Front to the north (the southern border of the Subtropical Frontal Zone, Belkin 1988; see also Belkin \& Gordon 1996). The study region comprises a part of the Campbell Plateau (depths largely between 200 and $500 \mathrm{~m}$ ) and, separate from the Plateau, the Bounty and Antipodes islands. To look for conspicuous island-associated chlorophyll increases, the waters around the Campbell and Auckland islands, outside the boxes, also were inspected.

Briefly reviewing hydrography and nutrients, concurrent images from other satellites for locating fronts or other hydrographic features were not consulted. Instead, average frontal locations from the literature were used as a reference frame (Fig. 1), which is apt to oversimplify the true situation. For the Southern Subtropical Front, the meridional variability is not well known, except that it and the other fronts are given to meandering (review in Patterson \& Whitworth 1990; satellite pictures in Rodionov 1993). While the SAF follows the large-scale bathymetry of the Campbell Plateau, its positions farther to the east might vary by about $2^{\circ}$ of latitude on both sides of the mean location (cf. Belkin 1988, Fig. I.3 therein). It is unclear which role previous criteria in locating the front versus actual seasonal or interannual differences may have played for the choice of the average position of the SAF. For example, using bimonthly presentations with 1 yr of monthly composites of AVHRR data (a satellite-borne Advanced Very High Resolution Radiometer), the front was placed near $48^{\circ} \mathrm{S}$ between $175^{\circ}$ and $180^{\circ} \mathrm{E}$ for April 1989 and February 1990, but did not stand out during the other 4 periods (Chiswell 1994). Also, offshore at $200 \mathrm{~m}$ depth between $49^{\circ}$ and $50^{\circ} \mathrm{S}, 170^{\circ} \mathrm{W}$, Bryden \& Heath (1985) twice observed an approximately north-south trending sharp salinity front that they associated, perhaps incorrectly, with the border between subtropical and subantarctic water because McCartney (1977) located the SAF at $54^{\circ} \mathrm{S}$ in this region. Significantly, at this site where the average orientation of the SAF is west-east, the current along the front first ran northward, but 7 mo later ran southward, perhaps because of the passing of a meander (see later section 'Sources of variability in pigment distributions'). There seems little disagreement or variability about the position of the $P F$ in the area at issue; the few deviating locations are to the south of the line in Fig. 1 (cf. Belkin 1988, Fig. I.3 therein). Recent hydrographic literature for the region southeast. of New Zealand also was reviewed in Heath (1985).

The few published nutrient data between the STC and the PF in the area indicate the usual pattern of Subantarctic waters, with intermediate phosphate and 
nitrate values, but quite low silicate concentrations north of the SAF; presumably, all nutrients attain high values south of the SAF. For the water downstream from New Zealand and north of the SAF, Gordon \& Molinelli (1982), based on scant data (cf. their Plate 39 for water density at $100 \mathrm{~m}$ ), depict phosphate at $100 \mathrm{~m}$ depth as generally being $>1 \mu \mathrm{M}$, or even $>1.5 \mu \mathrm{M}$. Nitrate is shown as $>10 \mu \mathrm{M}$ in most of the region except in our Box 4 and possibly in Box 1 (>5 $\mu \mathrm{M}$ ). Also for the well-lit period October-April, surface phosphate is high $(>0.5$ to $>1.0 \mu \mathrm{M}$; Bradford \& Roberts 1978), so that surface nitrate concentrations likewise can be expected to be appreciable. The map of Gordon \& Molinelli (1982) shows silicate as being $\leq 0.5 \mu \mathrm{M}$ on the Campbell Plateau, and $0.5<\mathrm{Si}<10 \mu \mathrm{M}$ in most of the rest of the region. Original surface silicate data over the Campbell Plateau (Japan Fisheries Agency 1972), however, were 2 to $3 \mu \mathrm{M}$ during November 1970 - January 1971, as also found there in May 1989 (Butler et al. 1992). Vinogradov \& Flint (1988) attempted a comprehensive treatment of the Subantarctic region between New Zealand and $125^{\circ} \mathrm{W}$, where similar nutrient values are reported.

\section{METHODS}

Data source and selection. The data were obtained from the CZCS Global Data Set (GDS; see Feldman et al. 1989) available within the Ocean Color Data Archive of the Distributed Active Archive Center of the NASA Goddard Space Flight Center (http://daac. gsfc.nasa.gov). We used the subsampled level Ia data (calibrated satellite radiance, subsampled for every 4 th pixel of every 4 th line so that 1 pixel at nadir represents about $16 \times 16 \mathrm{~km}$ ). All scenes collected with a gain of 1,2 , or 3 were processed, which during visual pre-screening appeared to offer valid pigment estimates within one of the boxes shown in Fig. 1.

Level II processing. Similar to the GDS, the atmospheric correction of the level Ia material was accomplished with the DSP software system developed at the University of Miami (Feldman et al. 1989, Evans \& Gordon 1994). The atmospheric-correction calculation of ozone and atmosphere thickness was updated over that used for the GDS (R. H. Evans 1993, pers. comm.), but the differences in the pigment estimates were usually slight. Similar to the GDS, we applied a default marine epsilon of 1.0, which for an examined subset of scenes was found to be generally appropriate. Note that atmospheric correction parameters varying from scene to scene may have a noticeable effect on the average CZCS pigment estimates, but will not artificially create localized blooms, in contrast to the effect of epsilon varying within a scene. Neither scene-to- scene nor within-scene determinations of epsilon were attempted because of the time that would have been required. The decay of the sensitivity of the sensor, especially noted since late 1982 (Evans \& Gordon 1994, also Sturm 1993), was incorporated in the processing. Even so, based on a few ground-truth values from the Arabian Sea for May 1986. Hay et al. (1993) suggested that the CZCS pigment concentrations are underestimates, at least for the last year of the sensor.

The resulting water-leaving radiance was converted with the algorithm used for the GDS into a nearsurface pigment estimate (chlorophyll a plus phaeopigment) and this level Ila product is designated fm4. For the circumpolar band between approximately $44^{\circ}$ and $50^{\circ} \mathrm{S}$, which is part of the domain of interest here, Fig. 2c of Sullivan et al. (1993) indicates that the algorithm approximates in situ concentrations well (cf. discussion in Banse 1996, p 248).

Cloud and cloud-ringing masks. The effect of sensor hysteresis after passing over bright clouds was reduced by adopting the cloud-screening procedure of Martin (1992), which expands the electronic overshoot algorithms of Mueller (1988), as described in English et al. (1996). This method identifies potentially contaminated pixels in the level II imagery, but may also remove error-free pixels. The product is called $\mathrm{cr} 4$. Except for Table 1, our paper is based on the cr4 processing. The effect of the procedure is illustrated in Fig. 2a. With the standard cloud mask of the GDS (left panel), narrow bands with very low pigment estimates can be seen immediately down-scan (to the right) of clouds, followed by broader regions of elevated pigment. Both of these regions are artifacts and are therefore eliminated (Fig. 2a, right panel). Most of the eliminated pixels were located down-scan of clouds

Whereas the median fraction of valid pixels for all dates for each box ranged from 25 to $40 \%$ (median, 36) in the fm4 product, the range in the cr 4 product was only 9 to $20 \%$ (median, 12). Thus, many observations were excluded by our procedure. Moreover, among the 7 boxes, 3 to $27 \%$ (median, 23) of the original dates with fm 4 data had only $<25$ pixels left after reprocessing and were dropped. Table 1 shows, however, that the cr 4 means are not markedly different from those for the fm4 product of the same scenes. For the 84 periods of January-June (44) and July-December (40) in the 7 boxes (1986 omitted) on which Table 1 is based, the range of the difference $\mathrm{cr} 4$ to $\mathrm{fm} 4$ (in $\mathrm{mg}$ $\mathrm{m}^{-3}$ ) is -0.26 to 0.23 , the median being -0.01 . Of the 13 negative and 5 positive differences $\geq 0.05,12$ occurred in the January-June period because most of these large differences accompanied high pigment means that are commoner in summer and autumn than in winter and spring (see Fig. 4). Note that even when means are not greatly changed by the reprocess- 
a

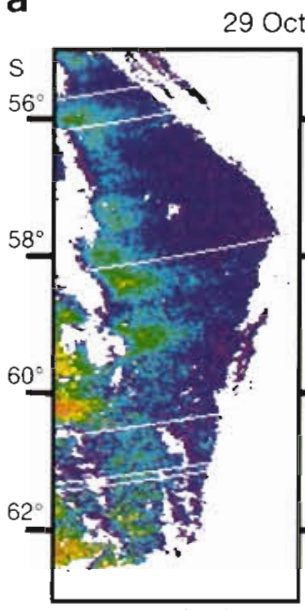

standard

cloud mask

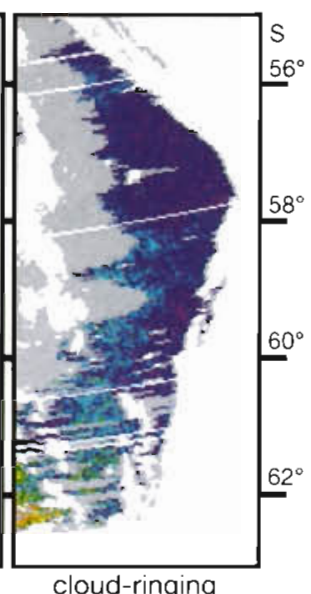

mask b

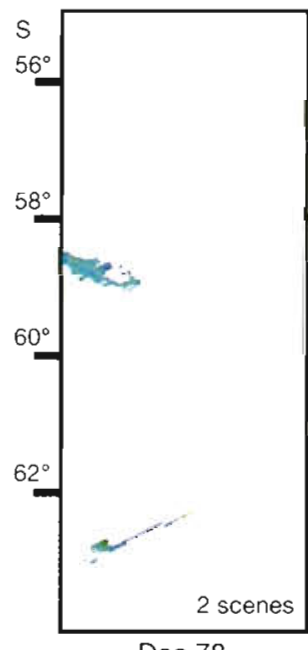

Dec 78

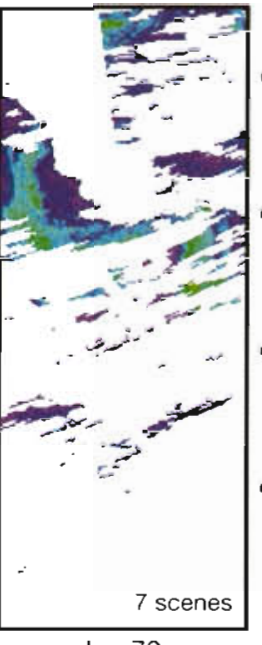

$\operatorname{Jan} 79$

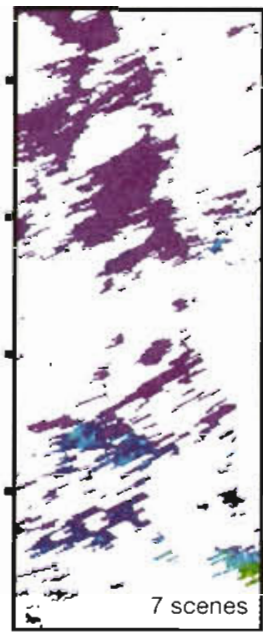

Feb 79

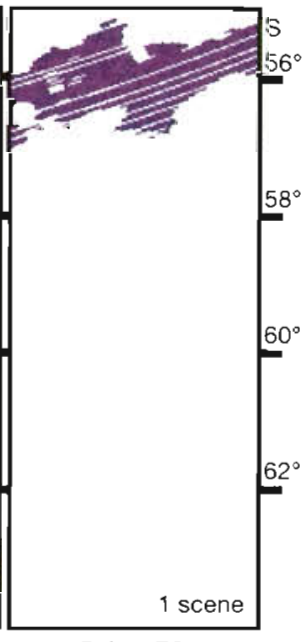

5 Apr 79

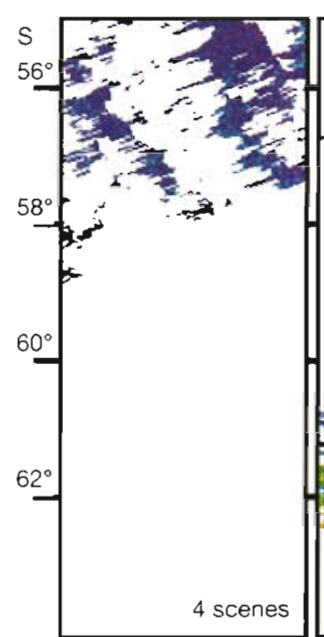

Sep 79

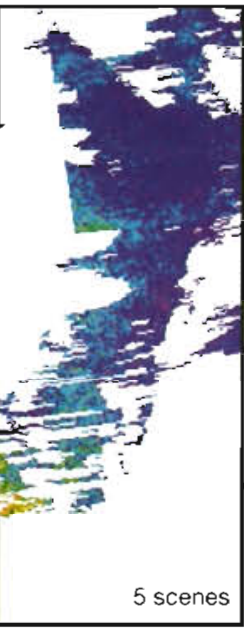

Oct 79

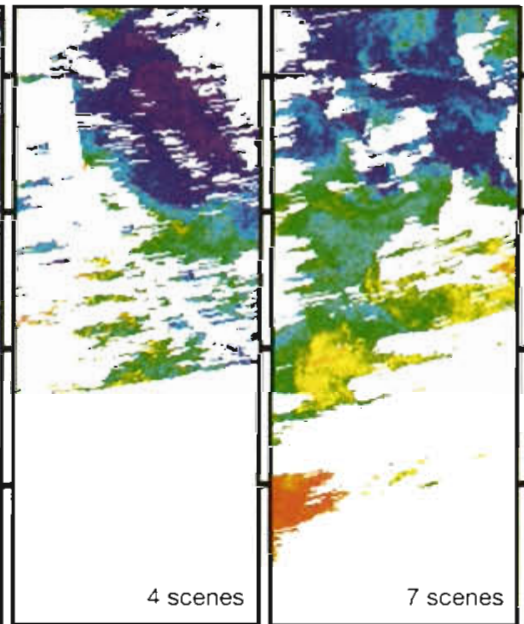

Dec 79
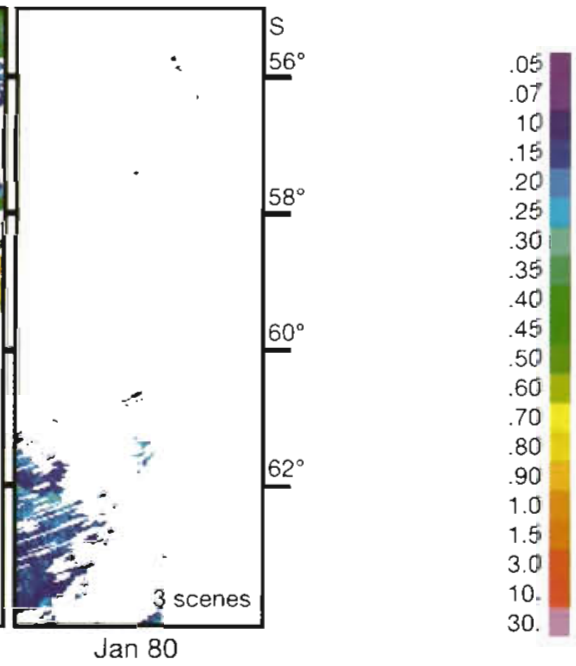

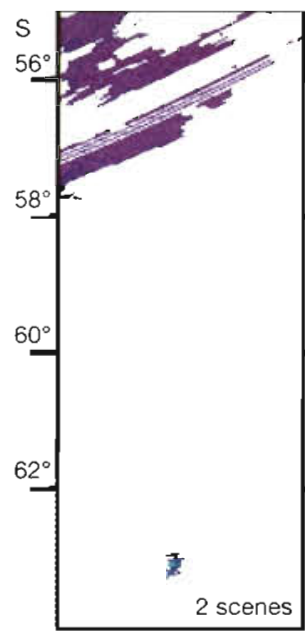

Oct 85

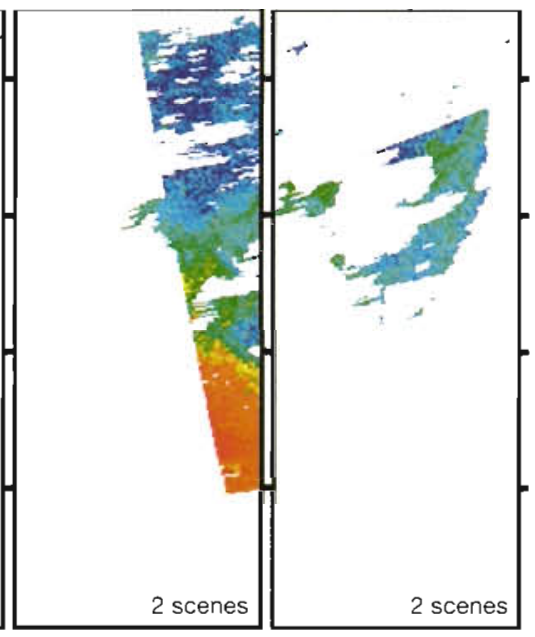

Nov 82

Dec 84

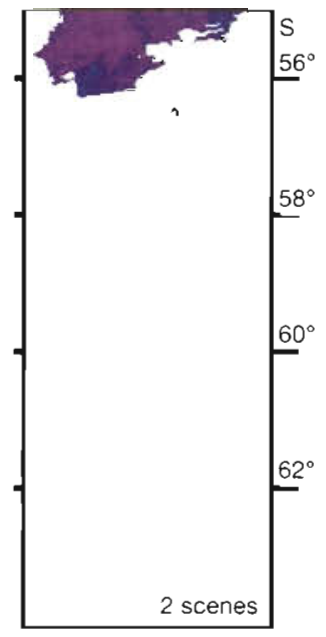

Feb 86

Fig. 2. Color Scanner images, with color bar indicating pigment ranges ( $\mathrm{mg} \mathrm{m}^{-3}$ of chlorophyll a and breakdown products). (a) $(2$ upper-left panels) A comparison of the scenes for 29 October 1979 with default processing as in the Global Data Set (fm4, left panel) and after cloud screening ( $\mathrm{cr} 4$, right panel); white: clouds or no coverage; grey: suspect pixels, omitted for this paper. (b) (remaining panels) Monthly cr4 averages for the U.S. JGOFS Box of Fig. 1 
Table 1. Means and medians of images with $>25$ pixels. There are more fm4 than cr4 images because after reprocessing $<25$ valid pixels may have remained. The cr 4 data are depicted in Fig. 4

\begin{tabular}{|ccccccc}
\hline \multirow{2}{*}{ Box } & \multirow{2}{*}{ Period } & \multicolumn{2}{c}{ Mean } & \multicolumn{2}{c|}{ Median } \\
& & fm4 & cr4 & & \\
& & & & \\
\hline \multirow{2}{*}{1} & Jan-Jun & 0.53 & 0.44 & 0.28 & 0.28 \\
& Jul-Dec & 0.24 & 0.24 & 0.21 & 0.21 \\
2 & Jan-Jun & 0.30 & 0.27 & 0.23 & 0.24 \\
& Jul-Dec & 0.25 & 0.23 & 0.17 & 0.18 \\
3 & Jan-Jun & 0.25 & 0.21 & 0.16 & 0.15 \\
& Jul-Dec & 0.17 & 0.16 & 0.15 & 0.15 \\
4 & Jan-Jun & 0.64 & 0.70 & 0.29 & 0.35 \\
& Jul-Dec & 0.33 & 0.30 & 0.23 & 0.21 \\
5 & Jan-Jun & 0.25 & 0.23 & 0.19 & 0.17 \\
& Jul-Dec & 0.32 & 0.33 & 0.20 & 0.20 \\
6 & Jan-Jun & 0.33 & 0.31 & 0.26 & 0.27 \\
& Jul-Dec & 0.32 & 0.33 & 0.28 & 0.28 \\
7 & Jan-Jun & 0.19 & 0.15 & 0.16 & 0.14 \\
& Jul-Dec & 0.26 & 0.25 & 0.19 & 0.18 \\
& & & & & \\
\hline
\end{tabular}

ing, standard deviations are usually lowered by the omission of extreme low and high values, so that smaller differences between means can be more confidently studied than is possible with the $\mathrm{fm} 4 \mathrm{p}$ product (see English et al. 1996 for the Pacific HNLC region at $50^{\circ} \mathrm{N}$ ).

Previously, we had noted that the new procedure labels as suspect most of the high pigment values (several

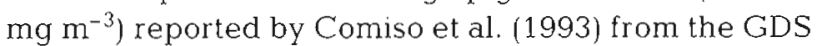
along $45^{\circ} \mathrm{E}$ and $135^{\circ} \mathrm{W}$, between $36^{\circ}$ and $51^{\circ} \mathrm{S}$, for late fall and mid-winter (Banse \& Enqlish 1994, p 7340). These blooms are not supported by the admittedly scant ground truth data (Banse 1996) and were deemed as unlikely for this time of the year. Similarly, Martin (1992) and English et al. (1996) had suggested for the eastern subarctic Pacific, at $50^{\circ} \mathrm{N}$ and about as cloudy as the area studied herein, that some high pigment means from the GDS appear to be artifacts.

Extraction of pixels and visual review for Boxes 1-7. To compute pigment statistics for the boxes (see Figs. 3 \& 4), all non-cloud pixels within a box were extracted for each scene or scenes. To check the quality of the cr4 product, means, medians, and standard deviations were plotted as yearly time series for all boxes (see Fig. 3 for Box 4, medians not shown). The imagery for more than two-thirds of the dates on which one or more boxes showed high standard deviations or seemingly atypical pigment means was visually inspected for processing artifacts, the presence of sharp pigment boundaries that might be associated with hydrographic fronts, and the shape and size of areas with increased pigment (in order to recognize the role of eddies). Also, the waters beyond the designated boxes were inspected when there was opportunity. Pigment values stated in the text are based on spot checks of images, hence, are only approximately representative, while distances were actually calculated. Because of the initial $4 \times 4 \mathrm{~km}$ subsampling, features smaller than about $20 \mathrm{~km}$ in size may have gone unnoticed.

To check whether pigment increases are associated with islands, island positions were entered in all images comprising Boxes 1-3. Only relatively large plumes would have been recognized because of the subsampling for the level Ia product. However, the size or diameter of such pigment enhancement, where it can be estimated from in situ work, ranged from about $40 \mathrm{~km}$ (Boden 1988 for Marion Is.) to $\geq 100 \mathrm{~km}$ (Plancke 1977 for the Kerguelen Is.).

\section{RESULTS AND DISCUSSION}

\section{The U.S. JGOFS Box}

Fig. $2 \mathrm{~b}$ illustrates the scant coverage at the highest latitudes that holds also for Boxes 3, 5, and 7 near $58^{\circ}$ to $60^{\circ} \mathrm{S}$. Even for Boxes 1, 2, 4 and 6 , the low frequency of imagery and heavy cloud cover very rarely permitted observation of the same area or conspicuous features more than once over a period of a few weeks.

For the northern part of the JGOFS Box, even during the months with long days, Fig. $2 \mathrm{~b}$ overall shows a very low pigment content, which is similar to the subtropical gyres depleted in nutrients. To the south of approximately $58^{\circ} \mathrm{S}$, the pigment is elevated to $0.5-0.6 \mathrm{mg}$ $\mathrm{m}^{-3}$ from November into January. Significantly in November and December 1979, with good areal coverage, the pigment enhancement is not a distinct ribbon, as observed elsewhere in situ in fronts (cf. Laubscher et al. 1993, Baar et al. 1995), but is clearly broad-based. The pigment ranges only approximately 2 -fold or less, except for a few spots in November with attained 0.65 to $0.8 \mathrm{mg} \mathrm{m}^{-3}$.

True blooms, with several $\mathrm{mg} \mathrm{m}^{-3}$ of pigment, appear in. the JGOFS Box only at and beyond $60^{\circ} \mathrm{S}$, i.e. presumably south of the PF. The high-pigment feature observed in the box in November 1982 extended to $150^{\circ} \mathrm{W}$ and $56^{\circ} \mathrm{S}$ with similar concentrations 10.6 to $0.7 \mathrm{mg} \mathrm{m}^{-3}$ ); it was separated from the water in the north, which had a concentration of approximately $0.15 \mathrm{mg} \mathrm{m}^{-3}$, by a wavy sharp edge, which we presume, from experience in other seas, to be associated with a hydrographic front. In addition to the 2 blooms in Fig. 2b, another area of high pigment approaching $1 \mathrm{mg} \mathrm{m}^{-3}$ (in places up to $1.4 \mathrm{mg} \mathrm{m}^{-3}$ ) was seen in late October 1979 at approx. $63^{\circ} \mathrm{S}, 170^{\circ} \mathrm{E}$, extending zonally over at least $150 \mathrm{~km}$ (end of cloud-free region). Also, in late October 1979, east of Box 7, south of $57^{\circ}$ to 
$58^{\circ} \mathrm{S}$ and between $154^{\circ}$ and $146^{\circ} \mathrm{W}$ (end of scene), a broad area with pigment ranging from 0.4 to 1.5 to $2.5 \mathrm{mg} \mathrm{m}^{-3}$ was present, which was separated by a sharp, wavy transition from the water with 0.2 to $0.25 \mathrm{mg} \mathrm{m}^{-3}$ to the north. One wonders whether this sharp border might have been at the PF. Similarly in mid-November 1979, a large field with concentrations of 1.5 to 2.5 (max. 3) $\mathrm{mg} \mathrm{m}^{-3}$ was recorded poleward of $57^{\circ} \mathrm{S}$ between $155^{\circ}$ and $152^{\circ} \mathrm{W}$; at this time, the waters south of Box 7 (i.e. south of $58^{\circ}$ and west of $160^{\circ} \mathrm{W}$ ) largely contained 0.2 to $0.25 \mathrm{mg} \mathrm{m}^{-3}$ (cf. Fig. 4, Box 7). The conspicuous pigment accumulation of midDecember 1979 in Fig 2b, on the same day, extended to at least $173^{\circ} \mathrm{E}$ with approximately 1.5 to $3 \mathrm{mg} \mathrm{m}^{-3}$ pigment, but north of $61^{\circ} \mathrm{S}$, the water was low in chlorophyll, similar to the panel. A comparable (or the same?) bloom was observed $11 \mathrm{~d}$ earlier near $61^{\circ} \mathrm{S}$, $178^{\circ} \mathrm{E}$, where $280 \mathrm{~km}$ of east-west extent were visible. Recall that the PF normally appears to run through the JGOFS Box between $60^{\circ}$ and $61^{\circ} \mathrm{S}$.

The bloom depicted for December 1979 also was noteworthy in being accompanied by in-water scattering, determined by comparing the normalized waterleaving radiances at 440,520 , and $550 \mathrm{~nm}$. The scattering was strong both in the high $\left(>1 \mathrm{mg} \mathrm{m}^{-3}\right)$ and intermediate $\left(>0.4 \mathrm{mg} \mathrm{m}^{-3}\right.$ ) pigment waters ( 7 December 1979). Probably, this scattering was caused by Coccolithophoridae and detached coccoliths. Depending on their size, they may lead to under- or overestimates of pigment by the CZCS (Gordon et al. 1988, Balch et al. 1989). Other light-scattering blooms, some of large east-west extent, were seen several times to the east and south of Box 7, presumably south of the PF.

The maps of mean ice coverage for the individual months of these years (Gloersen et al. 1992, Fig. 4.1 therein) show ice coverage of $>40$ and even $>60 \%$ to reach to $60^{\circ} \mathrm{S}$ only in some years and only at the height of the winter (August/September). During October and November 1979 , the ice edge (less than 10 to $15 \%$ coverage) was at about $64^{\circ}$ and $66^{\circ} \mathrm{S}$, respectively, and in November 1982 it was at about $64^{\circ} \mathrm{S}$. Thus, the blooms shown in Fig. 2b for December 1979 and November 1982 were open-sea phenomena and, from the latitude, presumably south of, or actually in, the PF. The pigment levels were clearly only 10 to $20 \%$ of the magnitude of a healthy bloom of the marginal ice zone.

In conclusion, the principal result regarding the JGOFS Box is the apparent absence of a pigment enhancement restricted to the $\mathrm{PF}$, as expected from observations elsewhere (Laubscher et al. 1993, Baar et al. 1995). Also, the panels for November and December 1979 with broadly elevated pigment in the Subantarctic water lack sharply delineated color features that might have been associated with hydrographic boundaries, in contrast to January 1979 (upper left of panel).
Outside the box in January's image, though, a circular structure of ca $50 \mathrm{~km}$ diameter with pigment somewhat higher than the surroundings was present at about $55^{\circ} \mathrm{S}, 170^{\circ} \mathrm{W}$

Second, large Subantarctic areas may exhibit raised pigment content in the austral summer, as will also emerge from the discussion of Boxes 1-7. In the JGOFS Box during the 8 mo period of 1979 for which there was data, supported by scattered observations from other years, pigment near $55^{\circ} \mathrm{S}$ may range seasonally between 5 - and 10 -fold, but it varies 10 - to 15 -fold between approx. $57^{\circ}$ and $60^{\circ} \mathrm{S}$. [These estimates assume not only the absence of winter blooms, but also that the pigment levels do not decline below the lower limit of the CZCS at $0.04 \mathrm{mg} \mathrm{m}^{-3}$; this is unlikely in view of the in situ data in Banse (1996).] Great as this range is, the highest means are very low by the standards of the temperate open North Atlantic or any temperate shelf and cannot be called true blooms. In January 1979, however, a large area with levels of slightly above $1 \mathrm{mg} \mathrm{m}^{-3}$ was present to the east of the box and extended to approximately $150^{\circ} \mathrm{W}$; such high levels have not as yet been seen in situ in the Pacific Subantarctic (Banse 1996).

Third, south of the PF, but almost certainly outside the domain of the marginal ice edge blooms of the months in question, the pigment range, as well as the concentrations, are appreciably larger than in the Subantarctic domain. The causes are obscure if these blooms occurred in water not seasonally ice-covered at all or which occurred only well after the marginal ice edge blooms had passed.

\section{Subantarctic waters downstream of New Zealand at large}

The re-processed CZCS data from Box 4

To introduce the overall temporal features, Fig. 3 contains the pigment means for all dates obtained for Box 4 . The box covers approx. $550 \times 750 \mathrm{~km}$ and is the one most complete in temporal coverage. The linear scale for the pigment is intended to emphasize the exceptional character of the blooms. The 3 observed blooms will be discussed in detail to illustrate the problems in arriving at explanations if no data other than temporal and spatial pigment distributions are at hand.

During most of the spring-to-fall period, pigment means in Box 4 were $<0.5 \mathrm{mg} \mathrm{m}^{-3}$, and even in midsummer often $\ll 0.5 \mathrm{mg} \mathrm{m}^{-3}$ (cf. Box 4 in Fig. 4). The standard deviations (SD) are often appreciably smaller than the means, indicating great spatial uniformity of pigment. This uniformity is further borne out by the common stability of values from date to date, even 

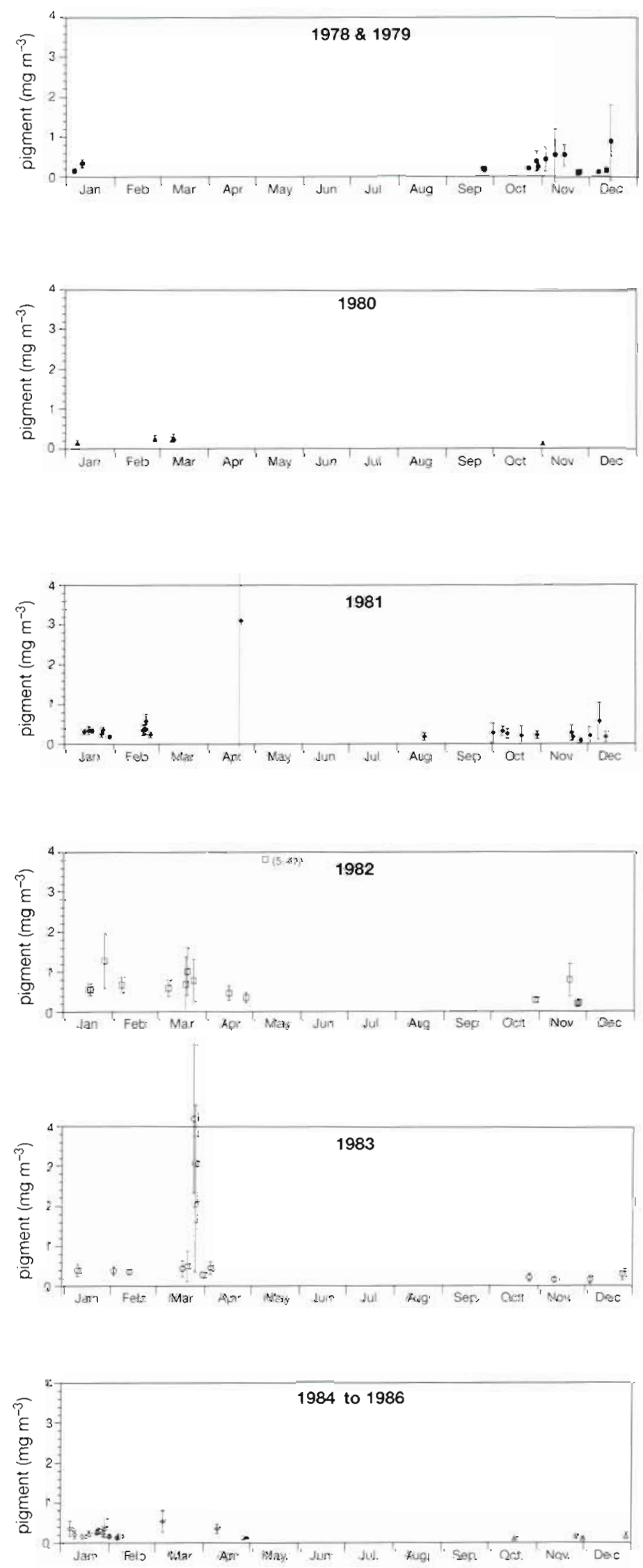

though on most days, only small parts (usually $<1 / 4$ to $<1 / 3$ ) of the box were visible. Means around $1 \mathrm{mg} \mathrm{m}^{-3}$ and above were observed only in summer (mid-December to late March).

Three dates or periods yielded means of $\geq 2 \mathrm{mg}$ $\mathrm{m}^{-3}$, accompanied by $\mathrm{SD}$ high relative to the means. The first instance, on 22 April 1981, was part of a large bloom, quite variable in pigment on a small spatial scale, which occurred mostly in the northwestern part of the adjoining Box 6 and to the north of it, where concentrations of 2 to $3 \mathrm{mg}$ $\mathrm{m}^{-3}$ were recorded over a wide area. Because the concentrations gradually diminished toward the eastern part of Box 6, the mean for that box in Fig. 4 is only near $1 \mathrm{mg} \mathrm{m}^{-3}$.

The second high mean, of 9 May 1982, was part of a solid bloom without much apparent internal structure that extended from New Zealand to the southeast through the northern half of Box 1 into Box 4 , and north of the latter to $180^{\circ}$ at $42^{\circ} \mathrm{S}$. To the southwest of Box 1 and toward New Zealand, however, the concentrations were only 0.5 to $0.6 \mathrm{mg} \mathrm{m}^{-3}$. Thus, the bloom might have been associated with the STC, in contrast to the large bloom of mid-March 1982, depicted by Harris et al. (1993, Fig. 4e therein; see next section). The third occasion, on 25/26 March 1983, was part of a bloom that built up, then declined over a much larger area than seen in Box 4 and will be treated in detail below.

When considering the possible reasons for the temporal and spatial patterns in these measurements, especially the apparent alternatives of advection versus local growth, consider the following. The straight line between the exit of Cook Strait (between North and South Islands), with commonly high chlorophyll concentrations, and the northern tip of Box 1/northwest corner of Box 4 is approx. $600 \mathrm{~km}$ long; this distance applies also to the STC just to the north of that corner but, of course, the front is not a straight line. The geostrophic currents east and southeast of South Island are weak until the SAF with its much stronger velocities is reached (Gordon et al. 1978 and Webb et al. 1991, both from geostrophic calculation $_{i}$ higher currents were measured with drifters by Hofmann 1985; Webb et al. 1991 and Hofmann 1985 also show somewhat elevated speeds in the STC). Assuming weak average

Fig. 3. Pigment means (cr4) with 1 standard deviation (SD) of individual dates for individual years in Box 4 , with pigment on a linear scale. For a mean without a bar, the SD was greater than the mean 
currents of $10(20) \mathrm{cm} \mathrm{s}^{-1}(0.2$ and $0.4 \mathrm{knots})$, a straightflowing current would traverse the $600 \mathrm{~km}$ in 70 (35) $\mathrm{d}_{\text {i }}$ the same time scale applies within the boxes. For the biological time scale, a difference between the instantaneous rates of cell division and mortality in a nascent phytoplankton bloom of $0.1 \mathrm{~d}^{-1}$ may be somewhat arbitrarily assumed; losses from sinking and vertical eddy diffusion can be neglected. This rate of net population growth would double a concentration in $7 \mathrm{~d}$.

Thus, even though there may be events leading to faster currents, features like the frequently found contiguous band of pigment emanating from Cook Strait and the northern terminus of the Southland Front along the east coast of South Island (Harris et al. 1993, Fig. $4 \mathrm{a}-\mathrm{a}$ therein), to a location in the STC north of the tip of Box 1/northwestern corner of Box 4, should be regarded as principally due to in situ processes, but not as advected 'fossil' concentrations. The same holds for pigment changes within the boxes on the scale of onethird to one-half of a box width.

Therefore, it is suggested that the described 2 highpigment events of 21 April 1981 and 9 May 1982 were part of blooms principally generated north of Box 4 , rather than advected from far to the west. It is not known whether the pigment seen inside of Box 4 had grown in open Subantarctic waters or in close association with the Southern Subtropical Front; off Box 1 and 4 (northern edge at $45^{\circ} \mathrm{S}$ ), a sharp color front, with high pigment to the north, normally is present north of $44.0^{\circ}$ to $44.5^{\circ} \mathrm{S}$. The areas covered by the 2 blooms were largely not delimited by sharp borders from pigment-poor water to the south.

Two other periods of high pigment concentrations in Box 4 and adjoining areas may further illustrate the uncertainties of explaining pigment patterns without additional evidence.

(1) During the third bloom in Box 4 (Fig. 3), large parts of Boxes 1 and 4 exhibited between 0.2 and $0.4 \mathrm{mg} \mathrm{m}^{-3}$ of pigment on 14, 18, and 21 March 1983. North of $44^{\circ} \mathrm{S}$, between the average locations of the southern and northern Subtropical Convergences (Fig. 1), the concentration was ca $0.25 \mathrm{mg} \mathrm{m}^{-3}$. However, $\geq 300 \mathrm{~km}$ to the west, southeast of the exit of Cook Strait, a broad expanse of water with ca $2 \mathrm{mg} \mathrm{m}^{-3}$ was present. On 25 March. Box 1 and also the northern part of Box 2 still contained 0.3 to $0.5 \mathrm{mg} \mathrm{m}^{-3}$, but in the northwestern part of Box 4 , water of 3 to 5 ( $\max$. 6) $\mathrm{mg}$ $\mathrm{m}^{-3}$ had appeared; to the north of the box, the concentrations were ca 0.7 to $1.3 \mathrm{mg} \mathrm{m}^{-3}$. On 26 March (with 2 CZCS orbits recording), the northwestern tip of Box 1 (all that was visible) and the northern region of Box 4 reached into a front-like feature of high pigment ( 3 to $5 \mathrm{mg} \mathrm{m}^{-3}$ ), stretching from the northern coast of South Island and of $f$ Cook Strait but not extending to Box 6 . By 31 March, the concentrations in Boxes 1 and 4 were low again, and there were no high pigment concentrations to the west of Box 1. The same held for the next date, 5 April. Thus, although the high pigment appeared in connection with a color front (and, as we believe from experience in better studied regions, with a hydrographic front), it seems that much of the waxing and waning had occurred within the area, rather than being advected zonally, because of the speed of development versus the distance from New Zealand. A loop-like lateral (meridional) movement of the STC (cf. Heath 1981), however, might have played a role.

(2) Fig 3 shows a rapid decline of pigment in Box 4 from 21 to $26 / 27$ November 1982. This demonstrably was an artifact: The high pigment concentrations on 21 November 1982 were observed in a large window in the cloud cover over the northern part of the box. The enriched water formed a spiral of $\geq 1 \mathrm{mg} \mathrm{m}^{-3}$ that moved into the poorer water in Box 4 from a huge, solid bloom (ca $2 \mathrm{mg} \mathrm{m}^{-3}$ ), which extended northward to $42^{\circ} \mathrm{S}$. The observations on 26 and 27 November, however, refer to the southern part of Box 4

The entire record of the re-processed CZCS data

The full body of results is plotted in Fig 4 on a semilogarithmic scale to permit easier recognition of differences among the predominantly low pigment concentrations. The overall pattern is similar to that for Box 4 : The overwhelming number of daily means is $<0.5 \mathrm{mg}$ $\mathrm{m}^{-3}$, and quite a few are $<0.1 \mathrm{mg} \mathrm{m}^{-3}$, in spite of the high nutrients of these waters (HNLC condition). The grand means of the reprocessed data for all boxes are principally between 0.15 and $0.33 \mathrm{mg} \mathrm{m}^{-3}$ of estimated pigment, with the exception of the higher means of the January-June periods in Boxes 1 and 4 (Table 1). In the table, the median of the means of $0.26 \mathrm{mg} \mathrm{m}^{-3}$ (0.27 for January-June, 0.25 for July-December) is appreciably higher than that for the surface in situ data for the entire Subantarctic domain of the Pacific Sector (Banse 1996, Fig. 5 therein). Except during summer, the in situ observations southeast of New Zealand did not differ from the overall Pacific Sector means 10.16 and $0.12 \mathrm{mg} \mathrm{m}^{-3}$ for spring/summer and fall/winter, respectively, each period delimited by the equinoxes).

Fig. 4 shows weak and irregular seasonality, if any, which is in marked contrast to the pronounced seasonal change of chlorophyll in the Antarctic region. The seasonal trend, with all years lumped together, suggests an approximately 5 -fold increase of pigment from January to April, especially obvious in Boxes 2 and 3, but apparent even in Boxes 5 and 6 if the questionable values for 1986 are neglected. In Boxes 1, 2, and 4 to 6 , some averages fall between 0.5 and $1.0 \mathrm{mg}$ $\mathrm{m}^{-3}$, the greater number occurring in austral autumn 

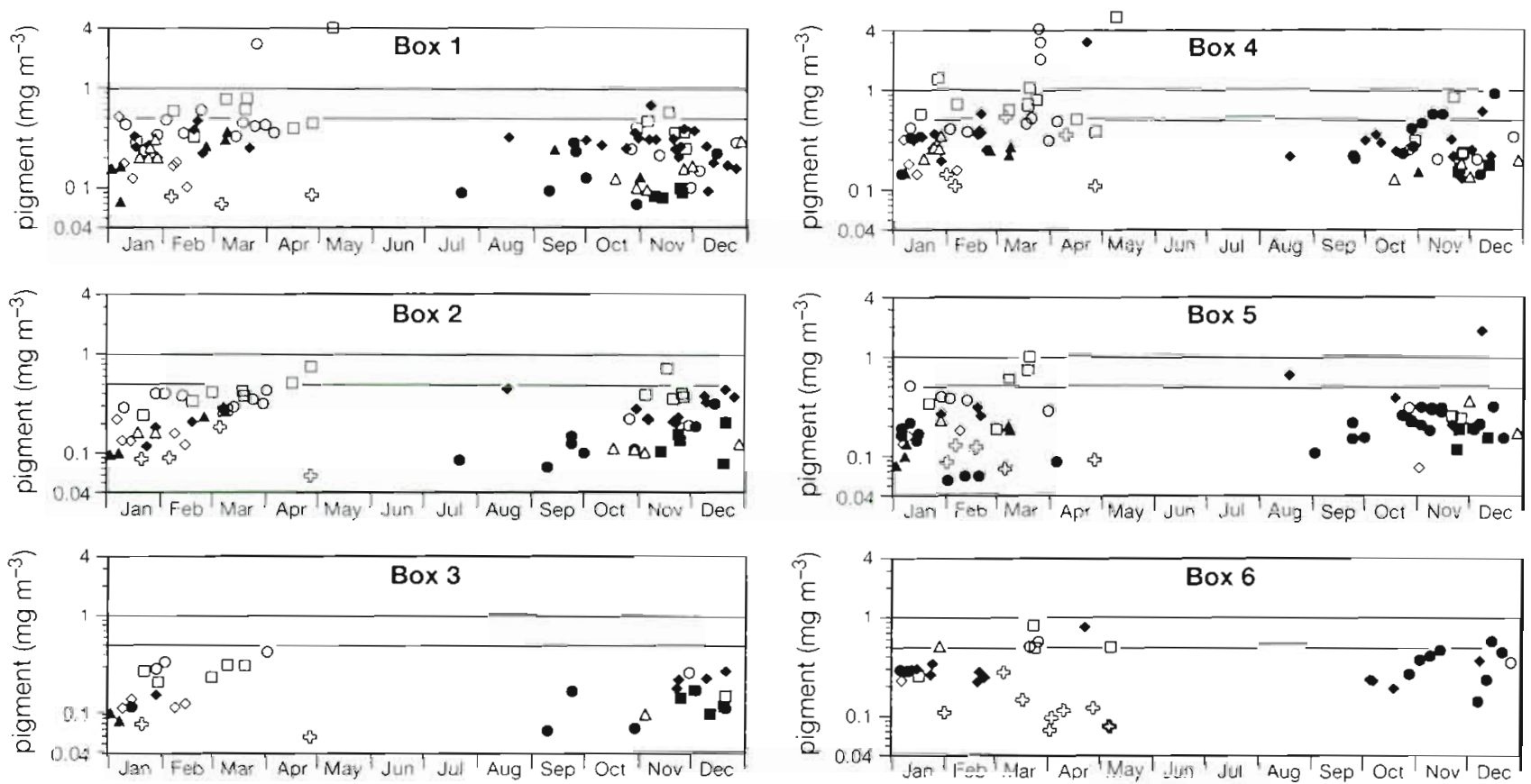

\begin{tabular}{llllll}
\hline 1978 & $\bullet 1981$ & $\Delta$ & 1984 \\
-1979 & $\square$ & 1982 & $\diamond$ & 1985 \\
$\Delta$ & 1980 & 0 & 1983 & $\&$ & 1986 \\
\hline
\end{tabular}

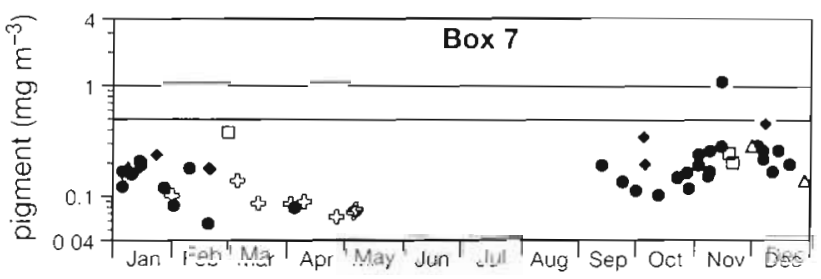

Fig. 4. All pigment means for individual dates in Boxes 1-7, with pigment on a logarithmic scale. Values north of $58^{\circ} S$ and inside the JGOFS Box are included in Boxes 5 and 7. Concentrations for 1986 may be questionable

(hence, the seasonal trend). In Boxes 1 and 4 such concentrations were also observed in spring and early summer of some years. Finally, all 3 dates with pigment concentrations well above $1 \mathrm{mg} \mathrm{m}^{-3}$ were recorded during autumn in Boxes 1 and 4 and were discussed in the preceding section.

Nothing quantitative can be made of the differences among boxes in Table 1 in view of the large variability in Fig 4 and the unsystematic interannual coverage (cf. the autumns in Boxes 6 and 7 ). It is most noteworthy, though, that there is no obvious trend from west to east. The apparent exception is the decline of means from Box 1 through 4 to 6 during summerautumn, which seems to be due to the frequent occurrence of blooms near the mean position of the Southern Subtropical Front, some of which extend into Boxes 1 and 4 but less often into Box 6 . This gradient of bloom occurrence may be caused by meandering of the front (cf. the southward deflection southeast of the Chatham Is. in Heath 1981 and the topography in Fig. 1). The lack of a west-east trend also suggests that neither New Zealand nor the Campbell Plateau exert a persistent influence on near-surface chlorophyll levels in the Subantarctic water at the longitudes and scales presented here. There is a weak trend towards higher means in the northern than in the southern boxes, i.e. approximately the waters to the north and the south of the SAF, respectively. This is surprising because, as stated, downstream of New Zealand, the waters north of the SAF are very poor in silicate. Apparently, this nutrient does not influence the average pigment content (compare Box 2 with Boxes 3, 5 and 7). Remarkably, the only large and intensive blooms occurred in the northern boxes (least so in Box 6). They may have been associated with frontal mixing in the Subtropical Front. As mentioned in the next section, there were also wide-ranging areas with somewhat increased pigment in the southern boxes, but they were more often interspersed with pigment-poor water, so that the means do not show it.

In regard to differences among years, recall that the CZCS pigment as calculated in the Global Data Set (GDS) for May 1986 has been questioned (Hayes et al. 1993). There is a trend towards higher values for the austral summers and autumns of 1982 and 1983 in Boxes 1-3, presaged in the springs of 1981 and 1982, 
respectively. The bloom period of March 1982 was depicted by Harris et al. (1993, Fig. 4e therein), as mentioned, but their observations were reported largely for north of $46^{\circ}$ to $47^{\circ} \mathrm{S}$, so that only the northern parts of Boxes 1 and 4 overlap with their picture of Subantarctic waters broadly in bloom.

Finally, the means in Table 1 are lower than suggested by a visual perusal of the maps by Comiso et al. (1993), which are based on the GDS and also depict some features appreciably smaller than our boxes. When averaged over the large areas of the boxes, however, the systematic difference between the results from the 2 procedures is small (Table 1, see also 'Methods'].

\section{Sources of variability in pigment distributions}

The following focuses on the kind and frequency of particular features, including color fronts at scales $>20$ to $30 \mathrm{~km}$, that might be encountered while at sea. All days with medium to high means and high standard deviations (63 out of a total of $159 \mathrm{~d}$ ) were visually inspected. In addition, patterns in Boxes $1-3$ were studied for $87 \mathrm{~d}$ to check for effects of islands and the Campbell Plateau on pigment; most of these images were not among those for the former $63 \mathrm{~d}$. Since the overlap between the 2 sets was not quantified, the percentages of occurrence (frequencies) of particular features, reported below, are approximate.

To the north of Boxes 1 and 4, water with a few $\mathrm{mg}$ $\mathrm{m}^{-3}$ of pigment seems to be regularly present; note that our coverage of that latitude was limited. Such water often extended into the northern parts of Boxes 1 and 4 , but rarely into Box 6 . The increased chlorophyll, illustrated for spring 1981/summer 1982 by Harris et al. (1993, Figs. 3 \& 4 therein), must be associated with the Southern Subtropical Front or eddies shed from it. The cause of the pigment increase is apt to be the mixing of oligotrophic subtropical with nutrient-rich Subantarctic water. Both gradual and sharp gradients of pigment were observed also between Box 4 and New Zealand. During a very few days, large areas of increased pigment in Box 1 and also Box 4 (>0.25, often $0.8 \mathrm{mg} \mathrm{m}^{-3}$ ) were separated from the more massive blooms to the north of the boxes by a narrow strip of water (a few tens of $\mathrm{km}$ wide) of 0.1 to $0.2 \mathrm{mg} \mathrm{m}^{-3}$. For example, on 9 March 1980, such pigment-poor water with $0.15 \mathrm{mg}$ $\mathrm{m}^{-3}$ was found in a $500 \mathrm{~km}$ long west-east band, separated by front-like edges from the high concentrations to the north and the lesser $\left(0.25 \mathrm{mg} \mathrm{m}^{-3}\right)$ values to the south.

Poleward of the boxes, i.e. south of the probable position of the PF, water with several $\mathrm{mg} \mathrm{m}^{-3}$ of pigment was likewise often encountered, definitely during summer and autumn; the coverage during spring was inadequate. The majority of these blooms were separated by a sharp color edge, often wavy or curled, from the pigment-poor water to the north, e.g. 1.5 to $2.5 \mathrm{mg}$ $\mathrm{m}^{-3}$ to the south versus 0.1 to $0.15 \mathrm{mg} \mathrm{m}^{-3}$ to the north. As stated for the JGOFS Box, the ice during those years had already retreated from the region in fall. Thus, these blooms could not have been associated with the marginal ice zone. Moreover, while they often could be seen to extend zonally over several degrees of longitude, there were often equally long stretches very poor in pigment at the same time (within days) and latitude. Thus, the cause of these blooms is obscure.

A band of pigment was not observed where the PF was expected. Based on in situ observations in other Subantarctic regions reviewed in Banse (1996), such an enriched belt of chlorophyll might be from 10 to $>100 \mathrm{~km}$ wide and, thus, would be recognizable in CZCS observations even after subsampling every 4 th pixel of every 4 th line. Similarly, west-east oriented enrichment in the region indicated in Fig. 1 as the location of the SAF did not seem to be a common feature, if it occurred at all; there were some questionable instances. Meridionally oriented color fronts in the boxes, however, were mostly bands of water quite poor in pigment $\left(0.1\right.$ to $\left.0.2 \mathrm{mg} \mathrm{m}^{-3}\right), \geq 100 \mathrm{~km}$ long and $20 \mathrm{~km}$ to a few tens of kilometers wide, which passed through pigment-rich water including true blooms. They might have been associated with meanders of the SAF (cf. Rodionov 1994) and were observed on 8 dates when large enough stretches of water in the southern halves of Boxes 4 and 6 (south of the influence of the STC) and in Boxes 2, 3, 5, and 7 could be seen. The dates with such meridional features as described comprised less than one-tenth of the images inspected in those boxes.

The next 3 paragraphs describe pigment increases and blooms of relatively small areal extent that are likely to have been generated within the boxes in Subantarctic water proper. These did not greatly elevate the particular box means, since they co-occurred with wide stretches of pigment-poor water; the dates are recognizable by the high SD and often also by the fact that the medians are appreciably lower than the means. Occurrences of high pigment in the northern halves of Boxes 1, 4, and 6 are omitted, as they may have been associated with or derived from the Southern Subtropical Front; also passed over are pigment increases in Box 2, which are treated later.

Addressing moderate pigment elevations first, there are many instances in which parts of a box contained water uniformly at a concentration of ca $0.2 \mathrm{mg} \mathrm{m}^{-3}$ of pigment, while other parts of the box exhibited double or in rare cases triple that concentration, again in fairly uniform distributions. The observations on days with high SD but low means (see Fig. 3) often showed eddy- 
like color patterns, usualiy streamers of increased pigment in pigment-poor water (e.g. 0.5 vs $0.2 \mathrm{mg} \mathrm{m}^{-3}$ ). without an obvious source from which the streamers might have been derived. Several times, round patches of pigment-rich water, with a similar concentration contrast as the streamers, of approximately $100 \mathrm{~km}$ diameter were observed, but the edges were diffuse (see also below, for patches around islands of approximately the same size). For Boxes 1-3 (except the north portion of Box 1), the instances comprise approximately one-eighth of the total surveyed. The very few in situ observations of physical eddies in these waters indicate diameters larger than those which would be expected from the Rossby radius of deformation (near $60 \mathrm{~km}$, Bryden \& Heath 1985; 100 and $200 \mathrm{~km}$, Rodionov 1994).

In the seemingly open Subantarctic waters of Boxes 3 , 5 , and 7 , concentrations of $\geq 1 \mathrm{mg} \mathrm{m}^{-3}$ (up to $5 \mathrm{mg} \mathrm{m}^{-3}$ ) were observed on 6 dates that, like the afore mentioned streamers, apparently were not derived from a large bloom, as was common to the north of or in the northern parts of Boxes 1, 4, and also 6. They extended for 65 to $200 \mathrm{~km}$ ( 3 dates). These observations from Boxes 3,5, and 7 are the least ambiguous signs that the waters downstream of New Zealand are not an ordinary HNLC regime. The 6 dates amount to about onetenth of the total inspected. Patches as sketched in this and the preceding paragraphs were not seen in the eastern Pacific Sector in a survey of 21 dates with low cloud cover between January 1979 and November 1981, most scenes being approximately between $45^{\circ}$ and $58^{\circ} \mathrm{S}, 85^{\circ}$ and $110^{\circ} \mathrm{W}$.

Box 2 is located in part on, in part downstream of, the Campbell Plateau. Here, Bradford (1980; also in Heath \& Bradford 1980) had reported elevated in situ chlorophyll values during one late fall/early summer (up to $2.5 \mathrm{mg} \mathrm{m}^{-3}$ above the Pukaki Rise in the southwestern corner of Box 1 that is $<500 \mathrm{~m}$ deep). Heath \& Bradford (1980) had suggested a positive influence of the plateau on phytoplankton via water column stability, but as previously mentioned, the statistical support for this, although significant, was weak. We reviewed the CZCS observations in Box 2 together with those on the plateau to the west and northwest (Fig. 1). Prominent were 8 occasions when pigment at and beyond the western edge of the box was clearly above the Subantarctic range, attaining 1 to $5 \mathrm{mg} \mathrm{m}^{-3}$ (3 $\mathrm{mg}$ in midwinter, cf. Fig. 4) on 6 of these dates, without apparently being derived from New Zealand and adjoining waters. There were also a few pigment enhancements within Box 2. However, overall, these occurrences are only about one-seventh of the days of observations for the box.

Thus, although the water in contact with the seabed will resuspend particles and, hence, introduce an iron source, this mechanism of enriching the surface seems usually to be inefficient. Considering that the depth of the Campbell Plateau is generally much greater than $200 \mathrm{~m}$, the question arise: Is the time needed for vertical eddy diffusion to result in enrichment too short, and does frontal shear not take its place, in contrast to the observations made by Baar et al. (1995) at the PF in the Atlantic Sector?

\section{Open-sea Subantarctic islands}

Previously, increased phytoplankton or chlorophyll was very often found near islands in the Subantarctic and to the south. As reviewed by Banse (1996), explanations for the pigment increases, when offered, were couched in terms of water column stability and the resulting better light climate for growth, but the correlation of pigment with the depth of the mixed layer was usually poor. With the advent of the iron hypothesis, the sea bed as a source of the element has to be considered as well. To study island effects, all dates for Boxes 1-3 were inspected. The assumption was that, since pigment increases of small extent or blooms were scattered through the boxes as shown, growth conditions near the islands would be further enhanced because of the putative iron effect, possible water stabilization from runoff, and reduction of mixing depth by the sea bed. Hence, frequent or even regular pigment increases would be expected near islands.

The positions of at least one among the Bounty, Antipodes, Auckland, and Campbell islands were on images on $87 \mathrm{~d}$. However, between late October and mid-March, islands were actually visible only on 23 out of these days. The Antipodes Is. were seen 15 times, the Bounty Is. 10 times, and the Auckland and Campbell islands 3 times. Among these, clouds interfered with an interpretation of 2 cases, and the Antipodes Is. were in a wide-spread bloom for 2 successive days. Of the remaining 24,17 cases showed islands in waters of usually 0.1 to 0.15 , sometimes of $0.3 \mathrm{mg} \mathrm{m}^{-3}$ of pigment, but there was enhancement neither around the entire islands nor as a plume originating from the islands' positions. Among the last 7 cases, all from November through March, 5 showed the islands in or near the center of fairly regular circles of roughly $100 \mathrm{~km}$ diameter where the pigment had approximately doubled over that in the surrounding waters (to usually 0.4 , once approaching $0.6 \mathrm{mg} \mathrm{m}^{-3}$ ). Patches of a similar size and outline, however, with approximately the same level of enhancement over the surrounding waters of 0.1 to $0.2 \mathrm{mg} \mathrm{m}^{-3}$, had often been encountered in all boxes, as mentioned earlier. In the remaining 2 cases, i.e the Auckland and Campbell islands viewed on the same date, irregular fields of pigment, of 
4 and $1 \mathrm{mg} \mathrm{m}^{-3}$, respectively, and of about $100 \mathrm{~km}$ extent, were seen to the north and east of the islands. Patches even more irregular, with up to $1 \mathrm{mg} \mathrm{m}^{-3}$ of pigment, occurred on the same day to the west and southwest, but they were separated from the island areas by pigment-poor water.

Thus, on the scale studied, the islands normally do not enhance pigment, if they do so at all, although they are of volcanic origin and basalt has a high iron content. It is strange that the islands, when surrounded by somewhat increased chlorophyll, were centrally located rather than at the upstream end of a plume, if the cause for the enhancement was the island. Why does the contact of water with the sediment not regularly have a strong effect on the phytoplankton in a supposedly iron-poor environment, in contrast to a number of the cited in situ data from other Subantarctic and Antarctic islands? The lack of an effect is even more enigmatic, as the bottom might also provide spores or viable cells as inoculum, thus providing a head start for the phytoplankton.

Summarizing the 2 last sections, we conclude from the nearly persistently low pigment in the clearly Subantarctic realm downstream from New Zealand that the area is a HNLC region, which implies scarcity of iron. Upon addition of relatively substantial amounts of the element, phytoplankton blooms with chlorophyll well in excess of $1 \mathrm{mg} \mathrm{m}^{-3}$ would develop, as observed elsewhere in Subantarctic waters (Banse 1996). Based on the fact that the SAF is very rarely distinguishable in the present data (cf. the meridional frontal features, however) and that the PF is not recognizable at all by such enhancement, it is inferred that deep water brought up at the fronts is not a material source of iron, in contrast to waters in the eastern Atlantic Sector (Löscher et al. 1997). In that sector southwest and south of Africa, as well as southwest of Australia, blooms do occur on these fronts, although not always (Banse 1996). Hence, it is inferred further for the Subantarctic water downstream of New Zealand that cyclonic eddies, which make deep water rise, will not ameliorate the HNLC condition in the upper layers. Might iron supplied by dust be the reason for those blooms observed inside the boxes that clearly are not derived from the adjoining STC or PF and are seen also above the Campbell Plateau?

\section{Dust supply to the area}

The source of dust is Australia. The principal period of dust storms on the continent is from September through March, with the maximum occurring in November/December, but the frequency varies greatly from year to year (Prospero et al. 1989, Fig. 58.7 therein). The material travels to the east and across New Zealand principally in the quarter DecemberFebruary, when out to the dateline the frequency of haze (as distinct from fog) is $>5 \%$ (see also the maps of aerosol radiance for summer and autumn, Comiso et al. 1993, Plate 6 therein). The fallout reaches the seabed also to the east and southeast of New Zealand, as evidenced by maps with conspicuous lobes of bottom minerals that extend to $160^{\circ} \mathrm{W}$ and beyond, at and north of $45^{\circ}$ to $50^{\circ} \mathrm{S}$ (Griffin et al. 1968 for chlorite and illite, Thiede 1979 for quartz); some fallout also reaches higher latitudes. The material collecting on snowfields on the South Island, much of it not of local origin, contains about $5 \%$ iron (Windom 1970).

The average rate of supply of aeolian iron may meet the needs of the phytoplankton, based on the following estimate: The yearly deposition rate of airborne material to the region may be as low as $100 \mathrm{mg} \mathrm{m}^{-2} \mathrm{yr}^{-1}$ (Duce et al. 1991), with 5\% iron. Assume that only $20 \%$ is dissolved (Young et al. 1991, from discussion of earlier data). This yields approximately $20 \mu \mathrm{M} \mathrm{m}^{-2} \mathrm{yr}^{-1} \mathrm{Fe}$ (see also the role of existing dissolved Fe on solution of new particles, Zhuang et al. 1990, and the importance of the acidic nature of potential wet deposition, Zhuang et al. 1992, working with dust of another origin). Take the primary production in the region to be as high as $120 \mathrm{~g} \mathrm{C} \mathrm{m}^{-2} \mathrm{yr}^{-1}$ (upper end of ranges in Berger 1989, Figs, $6 \& 7$ therein) and the new-production ratio to be as high as 0.5 (as in Baar et al. 1995 in a similar calculation; the new production is balanced by export to depth). This yields $5 \mathrm{M} \mathrm{m}^{-2} \mathrm{yr}^{-1}$ of removed $\mathrm{C}$ Using a molar $\mathrm{Fe} / \mathrm{C}$ ratio of $2 \times 10^{-6}\left(1-2 \times 10^{-6}\right.$ in Sunda et al. 1991 for an oceanic diatom; $3 \times 10^{-6}$ in Morel et al. 1991 for another strain of the same species), would result in an export demand of only $10 \mu \mathrm{M}$ $\mathrm{m}^{-2} \mathrm{yr}^{-1} \mathrm{Fe}$, if iron were exported as live phytoplankton. Instead, of course, the phytoplankton is first ingested and digested by zooplankton, regenerating much Fe from the cells (e.g. Hutchins \& Bruland 1994) and reducing the demand further; on the other hand, iron may also be removed inorganically (Wells et al. 1995), which increases the demand.

Thus, these tenuous annual budgets, at least, do not contradict the suggestion that aeolian iron plays a material role. The issue of localized blooms as observed in the area, however, has to be treated on much shorter time scales. First, in a HNLC area with a marked seasonal changes of irradiance, the phytoplankton production and, hence, its iron needs, will vary several-fold (e.g. estimated as 4 to 5 times at $50^{\circ} \mathrm{N}$ in the Subarctic Pacific HNLC region; Frost 1993). But then, downwind of Australia, the dust supply also varies seasonally several-fold, with the peak in summer, as cited. Lastly, even within a season, the dust will principally arrive in events and, at that time, most 
likely will not be uniformly broadcast. Therefore, temporally and spatially limited dust falls in an environment with a restricted availability of iron (the HNLC condition) must result in patches of water with an increased cell division rate of phytoplankton. As argued by Banse (1996; likewise Geider \& La Roche 1994), the increase will be especially marked for the large algal size fraction, which is not under heavy grazing pressure, and result in a bloom. This mechanism may be the cause for the rare but marked patches of pigment $\geq 1 \mathrm{mg} \mathrm{m}^{-3}$ in the boxes. Without in situ measurements, this remains an inference.

\section{OVERVIEW}

This study is based only on CZCS observations, done in a very cloudy region and treated against the backdrop of the average hydrography and of general information on the Subantarctic HNLC domain elsewhere in the Pacific and Indian sectors. The CZCS data would be most useful when combined with studies by other satellites or in situ. Their absence weakens our interpretations. However, in spite of the infrequent images that are usually fragmented by clouds, with valid data restricted to small parts of the boxes, the following results seem secure:

(1) The average pigment level in this nutrient-rich, cool-temperate area, with high irradiance during summer, is approximately as low as in the other HNLC regimes, but not higher as sometimes extrapolated from previous CZCS-based studies.

(2) The Subantarctic islands, the region above and downstream from the Campbell Plateau, and the putative positions of the SAF and PF are not sites where near-surface chlorophyll is regularly increased. Pigment patterns suggesting the effect of other hydrographic fronts, eddies, etc., are largely absent inside the studied Subantarctic domain. However, elevated pigment occurs occasionally in medium-sized irregular patches in the interior of the boxes.

From (2), it is inferred that deep water, which may upwell and mix along fronts, is not a major source of iron in this area. Instead, aeolian supply of iron from Australian deserts may be the important, although a temporally and spatially irregular, source of the element to the offshore regions. This mechanism would be a possible explanation for the restricted occurrence of the offshore enhancements, found principally in autumn, and their absence in the eastern part of the Subantarctic Pacific. Because of the dust generated in Patagonia (Kumar et al. 1992), the mechanism may also operate to the east (downwind) of South America where the CZCS shows a long, similar plume of pigment-enriched water (e.g. Sullivan et al. 1993).
(3) The Subantarctic waters southeast of New Zealand are interpreted here as a HNLC region, principally on account of the persistently high macronutrients (N, P) and the year-round low chlorophyll values (for in situ data, see comments in the 'Introduction', as well as the CZCS observations in Fig. 4). Yet, a regular effect of the seabed on near-surface pigment is lacking (cf. especially the Subantarctic islands), thus casting doubt on the key role of iron for chlorophyll enhancement in these waters. However, high pigment occurrences (well above $1 \mathrm{mg} \mathrm{m}^{-3}$ ) are observed in patches in the center of the boxes, again primarily in the summer-autumn period, that are apparently not related to the Subtropical Frontal Zone or to water south of the estimated position of the PF and may be due to dust falls.

An alternative explanation of these isolated blooms, which are not observed in the eastern Pacific Subantarctic, is grazing by advected neritic mesozooplankton. This scenario, which is unsupported by data, is not mutually exclusive with that for iron from dust falls. Both proposed mechanisms have in common the vicinity of land although the land in question is the shelf of New Zealand, rather than the interior of Australia, for the following reason. Phytoplankton concentrations in a HNLC regime may increase by some amount when the normal tight balance between small zooplankton (mostly protozoans) and very small phytoplankton cells is disturbed by reducing the stock of the small zooplankters through predation from larger animals, and keeping it low for a period of perhaps 1 to $2 \mathrm{wk}$. The resulting extra pigment would consist of small cells. The iron assays from Antarctic waters, presumed to be applicable to the Subantarctic, showed that usually there is enough iron to permit doubling, quadrupling or more of phytoplankton in the control bottles within the span of a week, which would occur in the free water as well (see Banse 1996). In the field, the agents for removing the small zooplankton would be salps or copepods and euphausiids. Salps, however, would also remove the small phytoplankton and should be discounted as the main agent for the question at issue, while crustaceans are inefficient feeders on the dominant small cells in such waters (Atkinson 1996). The big question regarding the crustaceans, however, would be about the source of their populations and why they would occur in such patches of $\geq 100 \mathrm{~km}$ size.

For the grazing scenario, the crustacean populations most likely would have to originate on the shelf of New Zealand rather than on the small shelves of the oceanic islands. The species would be tied to shelf waters by life cycles or winter food levels. Neritic species even without bottom stages, once advected into the oceanic domain, are unable to reproduce at the quantity or 
quality (e.g. small cell size) of the food of the 'normal' high-latitude HNLC region, and hence, are basically restricted to the shelves. For expatriated specimens merely to survive, the temporal scale of 2 to 3 (4?) mo of advection into the interior of Boxes $4-7$ would not be excessive in view of the life length of cool-temperate species of copepods or euphausiids. The telltale in situ signs for this mechanism would be a highly increased concentration ( $\mathrm{mg}$ of pigment $\mathrm{m}^{-3}$ !) of the very small phytoplankton cells, accompanied by sub-normal amounts of small zooplankton (flagellates, ciliates). In contrast, an iron addition as the cause for materially enhanced chlorophyll would primarily increase the concentration of the large-celled phytoplankton. The proposed grazing mechanism would be at work also in the areas of increased chlorophyll discovered by the CZCS downstream of South America and the major island groups of the South Atlantic. The alternatives can be easily tested by in situ collections even from passing ships looking for features rather than following a pre-set station pattern

Acknowledgements. The preparation of this paper was supported by National Aeronautics and Space Administration grant No. NAGW-3606. We thank colleagues of the Coastal Zone Color Scanner Project of Goddard Space Flight Center for the production of the CZCS data in the Global Data Set. Drs I. M. Belkin and J. M. Bradford-Grieve kindly pointed to literature, valid criticism by 4 anonymous reviewers helped to tighten a few arguments, and Dr D. P. Henry and Mrs M. K. Talbot made suggestions regarding the style. Contribution No. 2181 from the School of Oceanography, University of Washington.

\section{LITERATURE CITED}

Anderson RF, Smith WO Jr (1995) U.S. JGOFS Southern Ocean Process Study Implementation Plan. US JGOFS Planning Coordination Office, Woods Hole Oceanogr Inst, Woods Hole, MA

Atkinson A (1996) Subantarctic copepods in an oceanic, low chlorophyll environment: cillate predation, food selectivity and impact on prey populations. Mar Ecol Prog Ser 130: $85-96$

Baar H.JW de, Jong JTM de, Bakker DCE, Löscher BM, Veth C. Bathmann U, Smetacek V (1995) Importance of iron for plankton blooms and carbon dioxide drawdown in the Southern Ocean. Nature 373:412-415

Balch WM, Eppley RW, Abbott MR, Reid FMH (1989) Bias in satellite-derived pigment measurements due to coccolithophores and dinoflagellates. J Plankton Res 11:575-581

Banse K (1996) Low seasonality of low concentrations of surface chlorophyll in the Subantarctic water ring: underwater irradiance, iron, or grazing? Prog Oceanogr 37 : 241-291

Banse K, Anderson GC (1967) Computations of chlorophyll concentrations from spectrophotometric readings. Limnol Oceanogr 12:696-697

Banse K, English DC (1994) Seasonality of coastal zone color scanner pigment in the offshore oceans. J Geophys Res 99 C:7323-7345
Belkin IM (1988) Basic hydrological features of the central part of the Pacific Sector of the Southern Ocean. In: Vinogradov ME, Flint MV (eds) Ecosystem of the Subantarctic Zone of the Pacific Ocean. Akad Nauk SSSR, Moscow, p 21-28 (in Russian) (Transl: Pacific Subantarctic ecosystems, New Zealand Transl Centre Ltd, Wellington, 1996)

Belkin IM. Gordon AL (1996) Southern Ocean fronts from the Greenwich mendian to Tasmania. J Geophys Res $101 \mathrm{C}: 3675-3696$

Berger WH (1989) Global maps of ocean productivity. In: Berger WH, Smetacek VS, Wefer G (eds) Productivity of the oceans: present and past. Wiley, Chichester, p 429-455

Boden BP (1988) Observations of the island mass effect in the Prince Edward Archipelago. Polar Biol 9:61-68

Bradford JM (1980) New Zealand region, surface chlorophyl] A. New Zealand Oceanogr lnst Chart, Misc Ser 44

Bradford JM, Roberts PE (1978) Distnbution of reactive phosphorus and plankton in relation to upwelling and surface circulation around New Zealand. NZ J Mar Freshwater Res 12:1-5

Bryden HL, Heath RA (1985) Energetic eddies at the northern edge of the Antarctic Circumpolar Current in the southwest Pacific. Prog Oceanogr 14:65-87

Burkholder PR, Burkholder LM (1967) Primary productivity in surface waters of the South Pacific Ocean. Limnol Oceanogr 12:606-617

Butler ECV, Butt JA, Lindstrom EJ, Tildesley PC, Pickmere S, Vincent WF (1992) Oceanography of the Subtropical Convergence Zone around southern New Zealand. NZ J Mar Freshwater Res 26:131-154

Chiswell $S$ (1994) Variability in sea surface temperature around New Zeuland from AVHRR images. NZ J Mar Freshwater Res 28:179-192

Comiso JC, McClain CR, Sullivan CW, R:un JP, Leonard CL (1993) Coastal zone color scanner pigruent concentrations in the Southern Ocean and relationships to geophysical features. J Geophys Res 98 C:2419-2451

Duce RA and 21 others (1991) The atmospheric input of trace species to the world ocean. Global Biogeochem Cycles 5:193-259

English DC, Banse K, Martin DL, Perry M.J (1996) Electronic overshoot and other bias in the CZCS Global Data Set: comparison with ground truth from the subarctic Pacific. Int J Remote Sens 17:3157-3168

Evans RH, Gordon HR (1994) Coastal zone color scanner 'system calibration': a retrospective examination. J Geophys Res 99 C:7293-7307

Feldman $G$ and 12 others (1989) Ocean color. Availability of the Global Data Set. EOS (Trans Am Geophy's Union) $70: 634-635,640-641$

Frost BW (1993) A modelling study of processes regulating plankton standing stock and production in the open subarctic Pacific Ocean. Prog Oceanogr 32:17-56

Geider RJ, La Roche J (1994) The role of iron in phytoplankton photosynthesis, and the potential for iron limitation of primary productivity in the sea. Photosynth Res 39: 275-301

Gloersen P, Campbell WJ, Cavalueri DJ, Comiso JC, Parkinson CL, Zwally HJ (1992) Arctic and Antarctic sea ice, 1978-1987 satellite passive-microwave observations and analysis. National Aeronautic Space Administration NASA SP-511, Washington, DC

Gordon AL, Molnelli EJ (1982) Southern Ocean atlas. Columbia Univ Press, New York

Gordon AL, Molinell EJ, Baker T (1978) Large-scale relative dynamic topography of the Southern Ocean. J Geophys Res 83 C:3023-3032 
Gordon HR, Brown OB, Evans RH, Brown JW, Smith RC, Baker KS, Clark DK (1988) A semianalytic radiance model of ocean color. J Geophys Res 93 D:10909-10924

Griffin JJ, Windom H, Goldberg ED (1968) The distribution of clay minerals in the World Ocean. Deep Sea Res 15:433-459

Harris GP, Feldman GC, Griffith FB (1993) Global oceanic production and climate change. In: Barale $V$, Schlittenbach PM (eds) Ocean color: theory and applications in a decade of CZCS experience. Kluwer Academic, Dordrecht, p 273-270

Hawes I, Gall M, Weatherhead M (1997) Photosynthetic parameters in water masses in the vicinity of the Chatham Rise, South Pacific Ocean, during late summer. NZ J Mar Freshwater Res 31:25-38

Hay BJ, McClain CR, Petzold M (1993) An assessment of the NIMBUS-7/CZCS calibration for May 1986 using satellite and in situ data from the Arabian Sea. Remote Sens Environ $43: 35-46$

Heath RA (1981) Oceanic fronts around southern New Zealand. Deep Sea Res 28:547-560

Heath RA (1985) A review of the physical oceanography of the seas around New Zealand-1982. NZ J Mar Freshwater Res 19:79-124

Heath RA, Bradford JM (1980) Factors affecting phytoplankton production over the Campbell Plateau, New Zealand. J Plankton Res 2:169-181

Hofmann EE (1985) The large-scale horizontal structure of the Antarctic circumpolar current from. FGGE drifters. J Geophys Res 90 C:7087-7097

Hutchins DA, Bruland KW (1994) Grazer-mediated regeneration and assimilation of $\mathrm{Fe}, \mathrm{Zn}$ and $\mathrm{Mn}$ from planktonic prey. Mar Ecol Prog Ser 110:259-269

Japan Fisheries Agency (1972) Report of the voyage of the investigations of the Kaiyo Maru 1970 in New Zealand waters. Japan Fish Agency, Tokyo (In Japanese). (Not seen in onginal, but from partial translation, Survey report of the Kaiyo Maru, 1970 offshore from New Zealand. Transl 82/1, New Zealand Oceanogr (nst)

Kumar N, Anderson RF, Mortlock RA, Froelich PN, Kubik P, Dittrich-Hannen B, Suter M (1995) Increased biological productivity and export production in the glacial Southern Ocean. Nature 378:675-680

Laubscher RK, Perissinotto R, McQuaid CD (1993) Phytoplankton production and biomass at frontal zones in the Atlantic sector of the Southern Ocean. Polar Biol 13: $471-481$

Leaky RJG, Fenton N, Clarke A (1994) The annual cycle of planktonic ciliates in nearshore waters at Signy Island, Antarctica. J Plankton Res 16:841-856

Löscher BM, Baar HJW de, Jong JTM de, Veth C, Dehairs F (1997) The distribution of $\mathrm{Fe}$ in the Antarctic Circumpolar Current. Deep Sea Res II 44:143-187

Martin DL (1992) Minimizing systematic errors in phytoplankton pigment concentration derived from satellite ocean color measurements. PhD thesis, Univ Washington, Seattle, WA

McCartney MS (1977) Subantarctic mode water. In: Angel M (ed) A voyage of discovery. Pergamon, Oxford, p 103-199

McClain CR, Koblinsky CJ, Firestone J, Darzi M. Yeh E-n, Beckley BD (1991) Examining several Southern Ocean data sets. EOS (Trans Am Geophys Union) 72:345, 351

Morel FMM, Rueter JG, Price NM (1991) Iron nutrition of phytoplankton and its possible importance in the ecology of ocean regions with high nutrient and low biomass. Oceanogr 4:56-61

Mueller JL (1988) Nimbus-7 CZCS: electronic overshoot due to cloud reflectance. Appl Optics 27:438-440

Patterson SL, Whitworth T (1990) Physical oceanography. In Glasby GP (ed) Antarctic sector of the Pacific. Elsevier, Amsterdam, p 55-93

Plancke J (1977) Phytoplankton biomass and productivity in the Subtropical Convergence area and shelves of the western Indian subantarctic islands. In: Llano GA (ed) Adaptations within Antarctic ecosystems. Smithsonian Inst, Washington, DC, p 51-73

Prospero JM (1981) Eolian transport to the World Ocean. In Emiliani C (ed) The oceanic lithosphere. The sea, Vol 7 Wiley, New York, p 801-874

Prospero JM, Uematsu M. Savoie DL (1989) Mineral aerosol transport to the Pacific Ocean. In: Riley JP, Chester R, Duce RA (eds) Chemical oceanography, Vol 10. Academic Press, London, p 187-218

Rodionov VB (1994) Structure of frontal zones in the Pacific sector of the Antarctic Ocean from satellite data. Sov $J$ Remote Sens 11:319-331 (translated from the Russian version of 1993)

Safi KA, Hall JA (1997) Factors influencing autotrophic and heterotrophic nanoflagellate abundance in five water masses surrounding New Zealand. NZ J Mar Freshwater Res 31:51-60

Sturm B (1993) CZCS data processing algorithms. In: Barale V. Schlittenhardt PM (eds) Ocean colour: concepts and applications in a decade of CZCS experience. Kluwer Academic Publs, Dordrecht, p 95-116

Sullivan CW, Arrigo KR, McClain CR, Comiso JC, Firestone J (1993) Distribution of phytoplankton blooms in the Southern Ocean. Science 262:1832-1837

Sunda WG, Swift DG, Huntsman SA (1991) Low iron requirement for growth in oceanic phytoplankton. Nature 351 : $55-57$

Thiede J (1979) Wind regimes over the late Quaternary southwest Pacific Ocean. Geology 7:259-262

Vinogradov ME, Flint MV (eds) (1988) Ecosystem of the Subantarctic Zone of the Pacific Ocean. Akad Nauk SSSR, Moscow (in Russian) (Transl: Pacific Subantarctic ecosystems, New Zealand Transl Centre Ltd, Wellington, 1996)

Webb DJ, Killworth PD, Coward AC, Thompson SR (1991) The FRAM atlas of the Southern Ocean. Inst Oceanogr Sci, Nat Envir Res Counc, Swindon, England

Wells NL, Price NM, Bruland KW (1995) Iron chemistry in seawater and its relationship to phytoplankton: a workshop report. Mar Chem 48:157-182

Windom HL (1970) Contribution of atmospherically transported trace metals to South Pacific sediments. Geochim Cosmachim Acta 34:509-514

Young RW and 10 others (1991) Atmospheric iron inputs and primary productivity: phytoplankton responses in the North Pacific. Global Biogeochem Cycles 5:119-134

Zhuang G, Duce RA, Kester DA (1990) The dissolution of atmospheric iron in surface seawater of the open ocean J Geophys Res 95 C: $16207-16216$

Zhuang G, Yi Z, Duce RA, Brown PR (1992) Chemistry of iron in marine aerosols. Global Biogeochem Cycles 6 $161-173$

Manuscript received: August 14, 1996

Revised version accepted: July 8, 1997 